\title{
MODEL REGRESI LOGISTIK UNTUK MELIHAT PENGARUH FAKTOR DEMOGRAFIS, SELF EFFICACY, TERHADAP PERILAKU MENCONTEK
}

\author{
Noor Lusty Putri Setiawati \\ uthykutii@gmail.com \\ Anggota HIMPSI Provinsi Jawa Barat
}

\author{
Agung priyono Utomo \\ agung@stis.ac.id \\ Fakultas Psikologi UIN Syarif Hidayatullah \\ Jakarta
}

\begin{abstract}
Adolescence is still a period of study in school. School is a secondary education environment for adolescents after the family environment. In school, teenagers are always faced with the assessment of the success of both teachers and teachers, both the success of the exam and schoolwork to know the progress of the level of achievement study. Measurement of learning outcomes tends to be quantitative, because the symbol of numbers or scores to determine the overall quality of student academic performance. This makes students competing, depressed and have a must in achieving high scores so that not infrequently the students do dishonest or cheat to achieve high score. One factor that is thought to lead to cheating behavior is self-efficacy. This research moved from the phenomenon of cheating behavior in junior high school students. The purpose of this study is to determine whether there is influence between self-efficacy and cheating behavior on students of Madrasah Pembangunan UIN Jakarta. Logistic regression models are used when all variables are categorical. Appropriate models are obtained after parameter estimation, significance test, and model fit test. In this study logistic regression model is used to determine the influence of Cheating Behavior, Self Efficacy, Class, Gender, Social Status and Religiuity. A sample of 128 people using two stage cluster sampling. Based on the analysis of logistic regression model concluded that the value of chi-square model of 63.1 and significance of 0.000, it shows that there is significant increase with the addition of self efficacy variable model, gender and religiuity to cheat behavior
\end{abstract}

Keyword: Cheating Behavior, Self Efficacy, Logistic Regression

\begin{abstract}
Abstrak
Masa remaja merupakan masa belajar. Sekolah merupakan lingkungan pendidikan sekunder bagi remaja setelah lingkungan keluarga. Di sekolah, remaja selalu dihadapkan pada situasi penilaian keberhasilan dari guru maupun ternan, baik dalam ujian maupun tugas sekolah. Pengukuran hasil belajar cenderung bersifat kuantitatif, lantaran simbol angka atau skor untuk menetukan kualitas prestasi akademik siswa. Hal ini membuat siswa berlomba -lomba, tertekan dan memiliki keharusan dalam meraih nilai yang tinggi sehingga tidak jarang siswa melakukan tindakan tidak jujur atau menyontek untuk meraih nilai tinggi. Salah satu faktor yang diduga dapat menimbulkan perilaku menyontek adalah self-efficacy (keyakinan dalam diri). Penelitian ini beranjak dari adanya fenomena perilaku menyontek pada siswa SMP. Tujuan penelitian ini adalah untuk mengetahui adakah pengaruh antara self-efficacy dengan perilaku menyontek pada siswa siswi Madrasah Pembangunan UIN Jakarta. Model regresi logistik digunakan saat semu variabel berbentuk kategorik. Model yang sesuai diperoleh setelah dilakukan panaksiran parameter, uji signifikansi, dan uji kecocokan model. Dalam penelitian ini model regresi logistik digunakan untuk mengetahui pengaruh Perilaku Menyontek, Self Efficacy, Kelas, Jenis Kelamin, Status Sosial dan Religiuitas. Sampel penelitian sejumlah 128 orang menggunakan two stage cluster sampling. Berdasarkan hasil analisis model regresi logistik disimpulkan bahwa nilai chi-square model sebesar 63.1 dan siginifikansi sebesar 0.000 , hal ini menunjukkan bahwa terdapat peningkatan signifikansi dengan penambahan model variabel self efficacy, jenis kelamin dan religiuitas terhadap perilaku menyontek
\end{abstract}

Kata kunci: Perilaku Menyontek, Self Efficacy, Regresi Logistik

Diterima: 05 April 2017 Direvisi: 15 Mei 2017 Disetujui: 25 Juni 2017 


\section{PENDAHULUAN}

Proses pendidikan adalah belajar yang melibatkan mental sehingga menghasilkan perubahan-perubahan dalam bersikap (Ihsan, 2008:2). Pelaksanaan pendidikan sesuai dengan tujuan pendidikan nasional yang tercantum dalam bab 2 pasal 3 yaitu untuk mengembangkan potensi peserta didik agar menjadi manusia yang beriman dan bertakwa kepada Tuhan Yang Maha Esa, berakhlak mulia, sehat, berilmu, cakap, kreatif, mandiri, dan menjadi warga negara yang demokratis serta bertanggung jawab (UU Republik Indonesia, 2003). Peningkatan sumber daya manusia, dan tujuan-tujuan dari pendidikan dapat ditunjukkan dengan tercapainya standar prestasi belajar. Pencapaian prestasi pendidikan perlu diukur untuk mengetahui kemajuan tingkat prestasi belajar siswa. Alat ukur yang digunakan ialah evaluasi belajar seperti ulangan dan ujian (Syah, 2007: 142). Menurut Syah (2007:141) kebanyakan pelaksanaan pengukuran hasil belajar cenderung bersifat kuantitatif, lantaran simbol angka atau skor untuk menentukan kualitas keseluruhan kinerja akademik siswa. Hal tersebut membuat siswa tertekan dan memiliki keharusan dalam meraih nilai yang tinggi bukan pada ilmu yang disampaikan. Hal ini memicu para siswa untuk berlomba -lomba untuk mencapai nilai tertinggi dan dianggap berhasil dalam belajar. Dalam mencapai nilai yang tinggi banyak hal yang dapat dilakukan siswa, tidak jarang siswa melakukan praktik-praktik yang terlarang seperti salah satunya menyontek sehingga tujuan dari tes atau ujian terabaikan. Alasan seseorang mencontek sangat beragam. Menurut (Anderman dan Murdock, 2007; Hartanto, 2012) berdasarkan perspektif motivasi, beberapa siswa menyontek karena sangat fokus pada nilai atau ranking di kelas, yang lain menyontek karena mereka sang at takut pada kesan yang akan diberikan oleh ternan sebaya mereka pada dirinya (yakni dianggap bodoh atau dijauhi) (Hartanto, 2012:5). Hal ini juga dikarenakan ada tekanan untuk mendapatkan nilai tinggi yaitu dari orang tua, ternan sebaya dan guru yang meyebabkan terjadinya perilaku menyontek (Murdock \& Anderman, 2006: 132).

Dengan pandangan tersebut membuat tekanan pada siswa untuk memperoleh nilai yang tinggi. Tekanan tesebut akan membuat para siswa lebih fokus tehadap nilai saja tapi bukan pada ilmunya. Menyontek lebih mungkin terjadi pada sekolah menengah pertama dan kelas tinggi daripada di kelas sekolah dasar karena praktik pembelajaran yang digunakan di sekolah-sekolah menengah dan sekolah tinggi lebih terfokus pada nilai dan kemampuan daripada yang terjadi di sekolah dasar (Anderman dan Murdock, 2007:2). Sejumlah penelitian menunjukan bahwa lingkungan sekolah menengah lebih terfokus pada nilai dan kinerja daripada sekolah dasar (Anderman \& Midgley, 1997; Anderman, 1998:84). Konsekuensi berkala, sebagai siswa pindah dari sekolah dasar ke sekolah menengah, meningkatnya fokus pada nilai dapat menyebabkan beberapa siswa untuk menyontek (Anderman, 1998:84). Siswa sekolah menengah pertama dan tinggi menyatakan bahwa tekanan untuk mendapatkan nilai tinggi yaitu dari orang tua, ternan sebaya dan guru yang meyebabkan terjadinya perilaku menyontek (Murdock \& Anderman, 2006:132). Terdapat beberapa pendapat yang menyebutkan faktor-faktor yang mempengaruhi perilaku menyontek. Anderman dan Murdock (2007) menyebutkan empat karakteristik yang mempengaruhi 
perilaku menyontek, pertama, karakteristik demographic meliputi, jenis kelamin, usia, status sosial-ekonomi dan religiusitas, kedua, karakteristik akademik meliputi, kemampuan (ability), area subjek dan institusi dan organisasi, ketiga, karakteristik motivasi, meliputi self-efficacy dan orientasi tujuan, keempat, karakteristik personality, meliputi tipe kepribadian dan locus of control.

Kenyataan tersebut juga terjadi di lokasi penelitian menunjukan kasus yang sama. Berdasarkan hasil wawancara yang peneliti lakukan terhadap guru dan sekaligus menjadi kepala sekolah di lokasi penelitian, didapatkan hasil bahwa, adanya perilaku menyontek yang dilakukan siswa pada saat ulangan/ujian ataupun pada saat mengerjakan tugas. Salah satu guru mata pelajaran muatan lokal di sekolah tersebut sering menemukan beberapa jawaban yang sarna antara siswa satu dengan yang lainnya. Selain itu peneliti juga melakukan wawancara terhadap siswa di MTS tersebut yang menyatakan bahwa ada beberapa temantemannya yang sering menyontek pada saat ulangan atau diberikan soal di dalam kelas oleh guru. Siswa menyontek karena kurang paham terhadap mata pelajaran yang diujikan dan belum ada persiapan menghadapi soal-soal atupun saat ada ulangan di sekolah sehingga kurang yakin dengan jawaban sendiri, takut salah dan mendapatkan nilai jelek. Dengan semakin banyak perilaku menyontek pada kalangan pelajar maka perlunya diantisipasi faktor-faktor yang dapat menyebabkan munculnya perilaku menyontek. Salah satu yang diduga dapat menyebabkan terjadinya perilaku menyontek yaitu self-efficacy atau yang disebut dengan keyakinan dalam diri individu akan kemampuannya sendiri (Alawiyah, 2011:5).

Menurut (Pajares 1996; Anderman \& Murdock, 2007:18) jika siswa memiliki self-efficacy tinggi maka akan memiliki rasa percaya diri yang tinggi pula dalam mengerjakan tugas, menghadapi ulangan ataupun ujian sehingga siswa akan cenderung menolak perilaku menyontek. Hal ini juga sesuai dengan pendapat (Murdock, Hale dan Weber 2001; Anderman dan Murdock, 2007:19) yang menyatakan bahwa keyakinan diri siswa yang rendah menjadi salah satu indikasi munculnya intensi perilaku menyontek siswa. Keyakinan akan kemampuan yang dimiliki oleh siswa dalam bertindak disebut self-efficacy. Siswa yang memiliki kebiasaan menyontek dapat dikatakan memiliki self-efficacy rendah atau low selffficacy. Hal tersebut senada dengan pendapat Hartanto (2012:23) yang menyebutkan bahwa gejala yang paling sering ditemui pada siswa yang menyontek ialah kebiasaan menunda-nunda tugas dan low self-efficacy.

Beranjak dari penjelasan di atas, maka peneliti merasa tertarik untuk meneliti keterkaitan antara self-efficacy dengan perilaku menyontek, dengan judul "Model Regresi Untuk Melihat Pengaruh Faktor Demografis, Self Efficacy Terhadap Perilaku Mencontek Pada Siswa Siswi Madrasah Pembangunan UIN Jakarta".

\section{Perilaku Mencontek}

\section{KAJIAN TEORI}

Perilaku menyontek menurut Kamus Bahasa Indonesia adalah mencontoh, meniru atau mengutip tulisan atau pekerjaan orang lain sebagaimana aslinya, selain itu perilaku menyontek didefinisiskan sebagai strategi yang digunakan siswa untuk meningkatkan kinerja (kinerja yang dimaksud disini adalah nilai) 
mereka dengan cara yang tidak benar (Anderman, Griesinger \& Westerfield, 1998) sedangkan menurut Athanasou dan Olasehinde (dalam Tyler et.al., 2010) menjelaskan bahwa perilaku menyontek sebagai keterlibatan siswa secara sadar atau partisipasi dalam penipuan yang dilakukan untuk memberikan persepsi kinerja yang baik pada tugas akademik.

Menurut Bushway dan Nash (1997), terdapat beberapa macam bentuk menyontek didalam kelas yaitu, menggunakan tempat menyimpan catatan pada saat ujian, mengopi jawaban dari teman, membiarkan yang lain mengopi lembar jawaban tugas. Dengan demikian, dari beberapa definisi perilaku menyontek yang peneliti kutip dari berbagai sumber bacaan tersebut, dapat disimpulkan bahwa perilaku menyontek merupakan strategi untuk meningkatkan prestasi nilai akademik dengan cara mencontoh, meniru, mengutip tulisan atau pekerjaan orang lain sebagaimana aslinya.Cizek dalam Anderman dan Murdock (2007) menyatakan bahwa perilaku menyontek terbagi menjadi tiga aspek, yaitu

1. Giving (memberi), taking (mengambil), atau receiving (menerima) information.

2. Menggunakan materi yang terlarang

3. Memanfaatkan kelemahan seseorang, prosedur atau proses untuk memperoleh keuntungan.

Anderman dan Murdock (2007) menyatakan bahwa terdapat beberapa faktor yang mempengaruhi menyontek. Faktor-faktor tersebut digolongkan kedalam empat karakteristik, yaitu demografi, akademik dan motivasi.

\section{Karakteristik demografi}

\section{Jenis kelamin}

Beberapa peneliti telah meneliti perbedaan jenis kelamin pada perilaku menyontek. Kebanyakan dari penelitian telah mengoprasionalisasikan perilaku menyontek berdasarkan self-report pelajar. Penelitian yang dilakukan oleh Calabrese, Cochran dan Davis menemukan bahwa laki-laki lebih banyak menyontek dibandingkan dengan perempuan. Sedangkan penelitian yang dilakukan oleh Jacobson menemukan bahwa perempuan menyontek lebih banyak dibandingkan dengan laki-laki. Terdapat juga penelitian yang tidak menemukan perbedaan perilaku menyontek antara laki-laki dan perempuan seperti penelitian yang dilakukan oleh Haines. Jenis kelamin jarang ditemukan sebagai prediktor yang signifikan pada self-report perilaku menyontek.

\section{Usia}

Karakteristik siswa mengacu pada tingkat usia, tingkat usia dalam pendidikan dikaitkan dengan tingkat kelas individu yang sering dianggap sebagai faktor kontekstual yang mempengaruhi ketidakjujuran. Menurut Franklyn-Stokes, Newstead dan Haines, faktor usia memiliki hubungan dengan perilaku menyontek. Beberapa studi yang dilakukan oleh Jensen, menemukan bahwa pelajar yang lebih muda lebih mungkin menyontek dibandingkan dengan pelajar yang lebih tua ketika perbandingan ini dibuat antara siswa sekolah menengah atas (SMA) dan mahasiswa. 


\section{Status sosial-ekonomi}

Perilaku menyontek berdasarkan status sosial ekonomi siswa ditemukan bahwa perilaku menyontek pada siswa sekolah swasta (private school) yang memiliki status sosial-ekonomi lebih tinggi memilik tingkat menyontek lebih tinggi dibandingkan dengan siswa sekolah umum (public school) menurut Calabrese dan Cochran.

\section{Religiusitas}

Berdasarkan religiusitas, ditemukan bahwa perilaku menyontek lebih rendah terjadi pada kelas yang religiusitasnya lebih tinggi dibandingkan dengan kelas yang liberal (Rettinger \& Jordan, 2005). Sejalan dengan hal tersebut, Sutton dan Huba menemukan bahwa pelajar yang religiusitasnya tinggi lebih rendah untuk melakukan tindakan menyontek dan juga lebih sedikit dalam membenarkan menyontek.

\section{Karakteristik akademik}

\section{Kemampuan (ability)}

Newstead et. al. menekankan pada kompleksnya hubungan antara kemampuan (ability) dan perilaku menyontek. Beberapa penelitian telah menemukan bahwa kemampuan (ability) berhubungan dengan perilaku menyontek dan secara umum dipercaya bahwa siswa yang memiliki kemampuan (ability) yang rendah lebih mungkin untuk melakukan perilaku menyontek.

\section{Area subjek}

Bowers, Davis dan Ludvigson menyatakan bahwa area subjek sains, bisnis dan mesin diidentifikasi sebagai disiplin ilmu dengan indikasi tinggi adanya menyontek dibandingkan dengan area subjek disiplin ilmu seni dan sosial. Schab, menemukan level perilaku menyontek lebih tinggi pada area sains dan matematika.

\section{Institusi dan organisasi}

Dawkins menyatakan bahwa perilaku menyontek akan lebih mungkin terjadi pada siswa yang tinggal bersama dibandingkan dengan siswa yang individual dan menurut Brown dan Emmet siswa pada institusi yang lebih besar menyontek lebih banyak dibandingkan dengan siswa pada institusi yang lebih kecil

\section{Karakteristik motivasi}

\section{Self-efficacy}

Menurut Bandura, self-efficacy mengacu pada kondisi spesifik, dimana individu yakin pada kemampuannya untuk melakukan tindakan yang perlu untuk mendapatkan prestasi. Selanjutnya Pajares menyatakan bahwa siswa yang tinggi level self-efficacy akademiknya akan lebih percaya diri pada kemampuan dalam mencapai tujuanya dan menurut Finn dan Frone self-efficacy tidak hanya dapat memprediksi level menyontek tetapi juga dapat memberikan penilaian hubungan antara prestasi dan menyontek. 
Orientasi tujuan (goals orientation)

Beberapa siswa memiliki motivasi intrinsik yang bertujuan pada penguasaan materi (disebut juga mastery goals). Beberapa siswa lainya memiliki tujuan dengan motivasi ektrinsik terhadap pembelajaran seperti ingin mendapatkan nilai yang cukup baik untuk menjaga beasiswa olahraga atau menjauhkan hukuman yang diberi oleh orang tua. Studi mengenai perilaku menyontek yang dikaitkan dengan achievement goals menegaskan bahwa menyontek sering muncul pada siswa yang memiliki tujuan belajar bukan pada penguasaan materi dan menurut Huss, Giordano dan Davis, performance orientation memiliki hubungan yang positif dengan perilaku menyontek .

Harding et.al. (dalam Broeckelman \& Pollock, 2006) menyebutkan beberapa faktor yang mempengaruhi perilaku menyontek yaitu kurangnya persiapan, kurangnya motivasi, tekanan kelas, dan bahan materi yang terlalu sulit. Selain itu Holmes dan Sutherland-Smith menemukan bahwa faktor budaya memberikan kontribusi yang kuat dalam perilaku menyontek. Selanjutnya menurut Bennett, Finn, Frone dan Rettinger menyatakan beberapa faktor yang mempengaruhi siswa berprilaku menyontek yaitu rendahnya orientasi tujuan, academic integration, self-efficacy, academic performance, dan school identification. Mengingat banyaknya faktor yang mempengaruhi perilaku menyontek, maka dalam penelitian ini, peneliti hanya membahas dua faktor yang diduga mempengaruhi perilaku menyontek. Faktor-faktor tersebut dibedakan menjadi faktor karakteristik demografis dan karakteristik motivasi yaitu self efficacy.

\section{Self Efficacy}

Albert Bandura (dalam Feist, J. dan Gregory J. F, 2008: 415) mendefinisikan efikasi diri atau self-efficacy sebagai keyakinan manusia pada kemampuan mereka untuk melatih sejumlah ukuran pengendalian terhadap fungsi diri mereka dan kejadian-kejadian di lingkungannya. Sedangkan Ormrod (2008: 20) mengatakan bahwa efikasi diri (self-efficacy) adalah penilaian seseorang pada kemampuan yang ada pada dirinya sendiri untuk melakukan perilaku tertentu atau mencapai tujuan tertentu. Berdasarkan dari definisi para ahli tersebut, dapat disimpulkan bahwa efikasi diri atau self efficacy merupakan keyakinan yang dimiliki oleh manusia tentang kemampuan dirinya dalam melakukan suatu tindakan tertentu sehingga mencapai tujuan tertentu. Cervone D. dan Lawrence A. P. (2012: 257) mengatakan bahwa individu yang mempunyai efikasi diri tinggi menunjukkan upaya dan ketekunan yang lebih besar dan menampilkan sikap rendah diri yang lebih baik dibandingkan individu yang memiliki efikasi diri rendah. Selain itu individu yang memiliki efikasi diri yang tinggi memiliki tingkat kecemasan dan depresi yang rendah daripada individu yang memiliki efikasi diri yang rendah sehingga mampu menghadapi tugas dengan lebih baik. Berdasarkan pada pernyataan tersebut maka dapat dikatakan bahwa individu dengan efikasi diri yang tinggi adalah individu yang tidak takut menghadapi tantangan dan tidak mudah menyerah hingga tujuannya dapat tercapai. Sebaliknya, pada individu dengan efikasi diri yang rendah, mereka takut dalam menghadapi tantangan, dan cenderung untuk mudah menyerah jika merasa dirinya tidak mampu. 
Bandura (1997: 42-43) menyebutkan bahwa efikasi diri terdiri atas tiga aspek, antara lain sebagai berikut.

1. Tingkat Kesulitan (Level) Tingkat kesulitan yang dimaksudkan adalah tingkat kesulitan tugas yang dihadapi oleh individu. Apabila individu menghadapi tugas yang disusun menurut tingkat kesulitannya, maka efikasi diri individu akan cenderung terbatas pada tugas-tugas yang mudah, sedang atau bahkan sulit sesuai dengan batas kemampuan yang dimiliki individu tersebut. Semakin tinggi tingkat kesulitan tugas maka semakin tinggi pula tuntutan efikasi dirinya. Sehingga seseorang dengan efikasi diri yang rendah akan cenderung untuk mengindari tugas-tugas yang memiliki tingkat kesulitan yang tinggi.

2. Generalisasi (Generality) Generalisasi berkaitan dengan luas cakupan bidang tugas yang akan membuat individu merasa yakin pada kemampuannya. Apakah individu dapat merasa yakin pada kemampuannya hanya terbatas pada tugas atau situasi tertentu ataukah pada tugas atau situasi yang bervariasi. Pengalaman dalam menyelesaikan tugas dapat menimbulkan penguasaan pada bidang tersebut dan meningkatakan keyakinan untuk dapat menyelesaikan tugas yang mirip atau lebih luas lagi.

3. Tingkat Kekuatan (Strength) Tingkat kekuatan merupakan aspek efikasi diri yang berkaitan dengan tingkat kekuatan dari keyakinan atau pengharapan individu terhadap kemampuannya. Keyakinan yang kuat akan mendorong individu untuk terus berupaya mencapai tujuannya meskipun mendapatkan pengalaman yang tidak menyenangkan. Sebaliknya jika keyakinan yang dimiliki individu lemah akan membuat individu tersebut mudah goyah oleh pengalaman-pengalaman yang tidak menyenangkan.

Dalam penelitian ini, pengukuran self efficacy menggunakan skala Raft Schwarzer dari Universitas Freie, Berlin. Skala self-efficacy Raft pertama kali dikembangkan pada tahun 1981 oleh Jerusalem dan Ralf Schwarzer, yang versi aslinya dibuat dalam bahasa Jerman. Skala self-efficacy milik Ralf Schwarzer telah di adaptasikan dalam 14 budaya (Schwarzer dkk, 1996). Alasan peneliti menggunakan skala milik Ralf Schwarzer, dkk (1996) karena landasan teori yang di gunakan dalam penelitiannya menggunakan teori social cognitive milik Albert Bandura. Selain itu, menurut Ralf Schwarzer dkk (1996) koefisien reliabilitas skala self-efficacy milik Ralf Schwarzer antara 0,75 sampai 0,90 sehingga dapat dikatakan reliable dan juga dapat dibuktikan melalui validitas diskriminan dan validitas konvergen. Dengan demikian, skala ini dapat dipergunakan pada masa dan janka waktu yang berbeda. Selain itu, peneliti juga menambahkan item skala berdasarkan dimensi-dimensi self efficacy.

\section{Model Regresi Logistik}

Regresi logistik merupakan model regresi yang digunakan bila variabel responnya bersifat kualitatif, (Hosmer dan Lemeshow, 1989). Model regresi logistik sederhana yaitu model regresi logistik untuk satu variabel prediktor $\mathrm{X}$ dengan variabel respon $\mathrm{Y}$ yang bersifat dikotomi. Nilai variabel $\mathrm{Y}=1$ menyatakan adanya suatu karakteristik dan $\mathrm{Y}=0$ menyatakan tidak adanya suatu 
karakteristik. Model regresi logistik yang variabel responnya memiliki dua kategori disebut model regresi logistik biner.

Peneliti ingin melihat apakah probability untuk melakukan tindakan perilaku menyontek seseorang yang merupakan variabel dependen bergantung pada tinggi rendahnya skor pada variabel independen yang ditetapkan dalam penelitian ini yaitu faktor demografis dan self efficacy. Hipotesis yang hendak diuji yaitu: "Ada pengaruh yang signifikan antara faktor demografis dan self efficacy, terhadap perilaku menyontek".

\section{METODE PENELITIAN}

\section{Populasi, target populasi, dan unit sampel penelitian}

Populasi dalam penelitian ini adalah siswa-siswi Madrasah Pembangunan UIN Jakarta. Siswa-siswi yang dimaksud adalah siswa-siswi kelas VII (8 kelas), kelas VIII (6 kelas), dan kelas IX (6 kelas) yang berjumlah 549 orang. Target populasi dalam penelitian ini adalah siswa kelas VIII dan IX yang bersekolah di Madrasah Pembangunan UIN Jakarta. Jumlah siswa kelas VIII dan IX adalah sebanyak 364 orang. Siswa kelas VII tidak diikut sertakan dalam penelitian ini karena sedang melaksanakan kegiatan siswa baru sehingga siswa tersebut tidak diijinkan dalam penelitian ini.Unit sampel dalam penelitian ini adalah siswa-siwi kelas VIII A sampai VIII F yang bersekolah di Madrasah Pembangunan UIN Jakarta dengan kelas IXA sampai IX F.

Pengambilan sampel yang digunakan dalam penelitian ini yaitu metode probability sampling dengan menggunakan teknik clustersampling two stage yaitu teknik pengampilan sampel yg dilakukan dalam dua tahapan. Tahap satu adalah memilih kelas yang merupakan primary sampling unit atau (psu) dan tahap kedua yaitu memilih $\mathrm{n}$ yang ada pada kelas terpilih sebagai secondary sampling unit (ssu). Pada tahapannyadilakukan teknikstratisfiedrandom sampling digunakan karena populasi perlu dikelompokkan agar homogen dan kemudian baru di random. Strata 1 yaitu kelas VIII yang terdiri dari 6 kelas dan strata 2 yaitu kelas IX yang terdiri dari 6 kelas dalam setiap strata dibuat sehomogen mungkin dan antar strata se heterogen mungkin. Peneliti menentukan kelas sebagai sub populasi, peneliti menganggap bahwa tiap kelas memiliki karakteristik yang sama dalam mewakili populasi. Diperoleh estimasi proporsi sampel dengan hasilnya $\mathrm{n}$ kelas VIII terdiri dari 4 kelas dan kelas IX 4 kelas dipilih secara random. Kemudian untuk n sampel diperoleh hasil proporsi 73 orang untuk kelas VIII dan untuk kelas IX terdapat 55 dipilih dengan cara random. Sehingga dalam penelitian ini berjumlah 128 siswa yang terdiri dari kelas VIII dan IX.

\section{Variabel Penelitian}

Variabel penelitian yang akan diteliti dalam penelitian ini yaitu perilaku menyontek, kelas, self-efficacy, jenis kelamin, religiusitas dan status sosial. Dependent variable dalam penelitian ini adalah perilaku menyontek, sedangkan variabel lainnya merupakan independent variable.

\section{Definisi Operasional Variabel}

Berikut ini penjelasan definisi operasional dari masing-masing variabel: 
1. Perilaku Menyontek merupakan strategi untuk meningkatkan prestasi nilai akademik dengan cara mencontoh, meniru, mengutiptulisan, pekerjaan orang lain sebagaimana aslinya.Perilaku menyontek diukur dengan pernyataan berupa skala dengan 40 item sesuai dengan dimensi yang ada dalam variabel perilaku menyontek.Dan kategori 0 untuk siswa yang berperilaku tidak menyontek dan 1 untuk kategori siswa yang berperilaku menyontek.

2. Self Efficacy diperoleh dari skor yang didapat pada skala self efficacy yang meliputi dimensi level, srength, dan generality, berisi 35 item pernyataan. Lalu dikategorikan skor 0 untu ksiswa yang self-efficacy-nya rendah dan skor 1 untuk siswa yang self-efficacy-nya tinggi

3. Jenis kelamin adalah skor yang diberi kode angka 1 (perempuan) dibandingkan dengan skor skala yang diberi kode angka 0 (laki-laki).

4. Kelas atau tingkatan adalah skor yang diberi kode angka (0) untuk kelas VIII dibandingkan dengan skor (1) untuk kelas IX.

5. Religiuitas adalah skor skala yang diberi kode angka (0) bahwa dirinya merasa belum bias konsisten dalam menjalankan perintah agama dan menjauhi segala larangannya dan (1) menganggap dirinya merasa konsisten dalam menjalankan perintah agama dan menjauhi segala larangannya.

6. Status sosial adalah skor yang diberi kode angka (0) untuk siswa yang tidak diterima oleh teman sebaya dan angka (1) untuk siswa yang diterima oleh teman sebaya.

\section{Tabel 1}

Deskripsi Data VariabelPenelitian

\begin{tabular}{ll}
\hline Variabel & Keterangan \\
\hline Jenis Kelamin & Laki-laki \\
Religiusitas & Perempuan \\
& Tidak Konsisten \\
Penerimaan teman Sebaya & Konsistn \\
& Diterima \\
Self Efficacy & Tidak Diterima \\
& Rendah \\
Kelas & Tinggi \\
& Kelas VIII \\
Perilaku Menyontek & Kelas IX \\
& Tidak Menyontek \\
\hline
\end{tabular}

\section{Teknik Analisis Data}

Analisis data dalam penelitian ini menggunakan teknik statistic analysis regretion logistic dengan bantuan software SPSS. Analysis regretion logistic merupakan kumpulan dari teknik metode statistika model logistik atau model logit merupakan salah satu bagian dari analisis regresi yang digunakan untuk memprediksi probabilitas kejadian suatu peristiwa, dengan mencocokan data pada fungsi logit kurva logistik. Selain itu, Regresi logistik digunakan bila 
variabel responnya bersifat kualitatif, (Hosmer dan Lemeshow, 1989). Metode ini merupakan model linier umum yang digunakan untuk regresi binomial. Seperti analisis regresi pada umumnya, metode ini menggunakan beberapa variabel bebas, baik kontinum maupun kategorik. Regresi logistik tidak memerlukan asumsi normalitas, heteroskedasitas dan autokeralasi, dikarenakan varaibel terikat yang terdapat apada regresi logistik merupakan variabel dummy (0 dan 1), sehingga residualnya tidak memerlukan ketiga pengujian tersebut. Untuk asumsi multikolinearitas tetap dilakukan karena hanya melibatkan varaibel-variabel bebas. Untuk pengujiannya dengan melakukan goodness of fit test yang kemudian dilanjutkan dengan pengujian hipotesis (uji $\mathrm{x}^{1}$ ) guna melihat variabel-varaibel bebas mana saja yang signifikan, sehingga dapat tetap digunakan dalam penelitian. Selanjutnya, diantara variabel-variabel bebas yang signifikan dapat dibentukmenjadi sebuah matriks korelasi dan apabila tidak terdapat variabel bebas yang saling berkorelasi yang tinggi, maka dapat disimpulkan bahwa tidak terdapat gangguan multikolinearitas pada model penelitian. Berdasarkan keterangan di atas, maka untuk mendukung pengujian hipotesis dalam penelitian ini diperlukan analysis regretion logistic biner.

\section{HASIL PENELITIAN}

\section{Gambaran Umum Subjek Penelitian}

Total sampel pada penelitian ini berjumlah 128 orang dari kelas VIII dan IX. Berikut ini adalah daftar sampel yang menjadi subjek dalam penelitian ini. Dalam penelitian ini terdiri dari variabel respon $(\mathrm{Y})$ yaitu perilaku menyontek dan lima variabel prediktor $(\mathrm{X})$ diantaranya self efficacy, jenis kelamin, dan religiuitas terhadap perilaku menyontek. Adapun deskripsi variabel dalam penelitian ini akan digambarkan melalui tabel dibawah ini:

\section{Tabel 2}

\section{Gambaran Umum Subjek Penelitian}

\begin{tabular}{lll}
\hline Variabel & Frequensi & Presentase $\%$ \\
\hline Jenis kelamin & & \\
Laki-laki & 50 & 39,1 \\
Perempuan & 78 & 60,9 \\
Kelas VIII & 73 & 57,0 \\
Kelas IX & 55 & 43,0 \\
Religiuitas & & \\
Tidak Konsisten & 54 & 42,2 \\
Konsisten & 74 & 57,8 \\
Self Efficacy & & \\
Rendah & 83 & 64,8 \\
Tinggi & 45 & 35,2 \\
Tidak Menyontek & 47 & 36,7 \\
Menyontek & 81 & 63,3 \\
\hline
\end{tabular}

Berdasarkan tabel di atas dapat diketahui bahwa dari 128 subjek penelitian MTS Madrasah Pembangunan UIN Jakarta kelas delapan dansembilan, 128 subjek 
(63.3\%) menyatakan bahwa mereka menyontek pada kegiatan akademik dan 49 subjek (36.7\%) menyatakan Tidak Menyontek.

\section{Uji Hipotesis Penelitian}

1. Analisis regresi logistik variabel penelitian

Peneliti menguji hipotesis dengan teknik analisis regresi logistik menggunakan software SPSS 20. Dalam pengolahan data mengunakan regresi logistik peneliti melihat besaran Nagelkerke R Square untuk mengetahui berapa persen(\%) varians variabel dependen yang dijelaskan oleh variabel independen, melihat secara keseluruhan apakah variabel independen berpengaruh secara signifikan terhadap variabel dependen (uji model regresi logistik) dan melihat koefisien regresi dalam bentuk logit, odd dan probability.

2. Uji model regresi logistik

Peneliti melihat besaran Nagelkerke R Square untuk mengetahui berapa persen (\%) varians variabel dependen dalam satuan logit yang dijelaskan oleh variabel independen (Connell, 2006). Selanjutnya untuk tabel Nagelkerke R Square, dapat dilihat pada tabel berikut.

\section{Tabel 3}

Nagelkerke R Square

\begin{tabular}{lccc}
\hline Step & -2 Log likelihood & Cox \& Snell R Square & Nagelkerke R Square \\
\hline 1 & $88.978^{\mathrm{a}}$ & .462 & .631 \\
\hline a. & Estimation terminated at iteration number 20 because maximum iterations has been \\
& reached. Final solution cannot be found.
\end{tabular}

Peneliti melihat perolehan hasil dari tabel model summery pada bagian Nagelkerke R Square untuk melihat proporsi varian dari logit menyontek. Peneliti melihat nilai Nagelkerke R Square karena nilai Nagelkerke R Square adalah pengukuran ulang dari proporsi varian dari logit menyontek yang diperoleh dari tabel Cox \& Snell R Square sehingga mendapatkan batas nilai 1.0 (Connell, 2006). Oleh karena itu nilai Nagelkerke R Square bisa ditafsirkan seperti proporsi varian pada analisis regresi linier pada satuan logit. Bagi pembaca yang terbiasa dengan nilai $\mathrm{R}$ Square pada regresi linier maka pada penelitian ini lebih baik melihat nilai Nagelkerke R Square karena koefisienya memiliki rentangan hingga 1.0. Dari tabel 4.2, dapat dilihat bahwa perolehan Nagelkerke $\mathrm{R}$ Square sebesar 0.631 atau $63,1 \%$. Hal ini menunjukkan bahwa besarnya proporsi varian dari logit menyontek yang bisa dijelaskan oleh tiga variabel independen yaitu jenis kelamin, self efficacy dan religiusitas sebesar $63,1 \%$ dan sisanya yaitu $36,9 \%$ dijelaskan oleh variabel-variabel lain diluar penelitian ini.

Untuk menilai ketepatan penggunaan model regresi logistik yaitu untuk mengetahui apakah model regresi logistik sudah sesuai dengan data yang diperoleh maka dilakukan pengujian model fit seperti yang disarankan oleh Hosmer dan Lemeshow (2000). Pada tingkat signifikansi 5\% didaptkan nilai ChiSquare dengan $\mathrm{P}>0.05$. Hal ini menunjukkan bahwa model regresi logistik fit 
(sesuai) dengan data. Artinya dapat dinyatakan bahwa ada pengaruh yang signifikan dari seluruh variabel yaitu jenis kelamin, kelas, religiusitas, dan self efficacy terhadap perilaku menyontek.

\section{Hasil Logistic Regression Analysis}

\section{Tabel 4}

Chi-square Model

\begin{tabular}{|c|c|c|c|c|}
\hline \multicolumn{5}{|c|}{ Omnibus Tests of Model Coefficients } \\
\hline & & Chi-square & $d f$ & Sig. \\
\hline \multirow{3}{*}{ Step 1} & Step & 79.327 & 13 & .000 \\
\hline & Block & 79.327 & 13 & .000 \\
\hline & Model & 79.327 & 13 & .000 \\
\hline
\end{tabular}

Berdasarkan tabel di atas diatas dapat disimpulkan Chi-square Model sebesar 79.327, angka ini menjelaskan kemampuan model dalam memprediksi variabel terikat perilaku menyontek. Dimana siginifikansi sebesar 0.000 , hal ini menunjukkan bahwa terdapat peningkatan signifikansi dengan penambahan model variabel self efficacy, jenis kelamin, kelas, dan religiusitas.

\section{Signifikansi Variabel}

Langkah selanjutnya adalah melihat koefisien regresi dari setiap variabel independen. Jika sig. $<0.05$ maka koefisien tersebut signifikan yang berarti bahwa variabel independen tersebut memiliki dampak yang signifikan terhadap perilaku menyontek. Penjelasan regresi logistik dijelaskan dalam bentuk logit, odds dan probability. Logit atau log odds adalah log dari ratio dua probability. Odds adalah ratio dari dua probability. Odds ratio yaitu ratio dari dua odds dan persen perubahan odds ratio adalah nilai persen perubahan pada odss ratio. Probability adalah peluang terjadinya perilaku dimana dalam penelitian ini adalah peluang terjadinya perilaku menyontek. Selanjutnya, dapat diketahui juga nilai rentangan probabilitas yang mungkin terjadi yang disebut confidence interval. Pertama, penjelasan nilai koefisien regresi dalam satuan logit. Logit memiliki rentang nilai $-\infty$ (negatif tidak terhingga) sampai dengan $+\infty$ (positif tidak terhingga). Berdasarkan nilai pada tabel 4.5 , persamaan regresi dalam satuan logit adalah sebagai berikut: (*signifikan)
Log odds (perilaku menyontek) $=22,592+0,354$ *jenis kelamin $(1)+1,374$ *kelas (1) + 1,395*Religiuisitas (1) + 1,197 *Self Efficacy (1).

Adapun untuk lebih jelas koefisien regresi yang dihasilkan seperti pada tabel berikut ini. 


\section{Tabel 5}

Koefisien regresi

Variables in the Equation

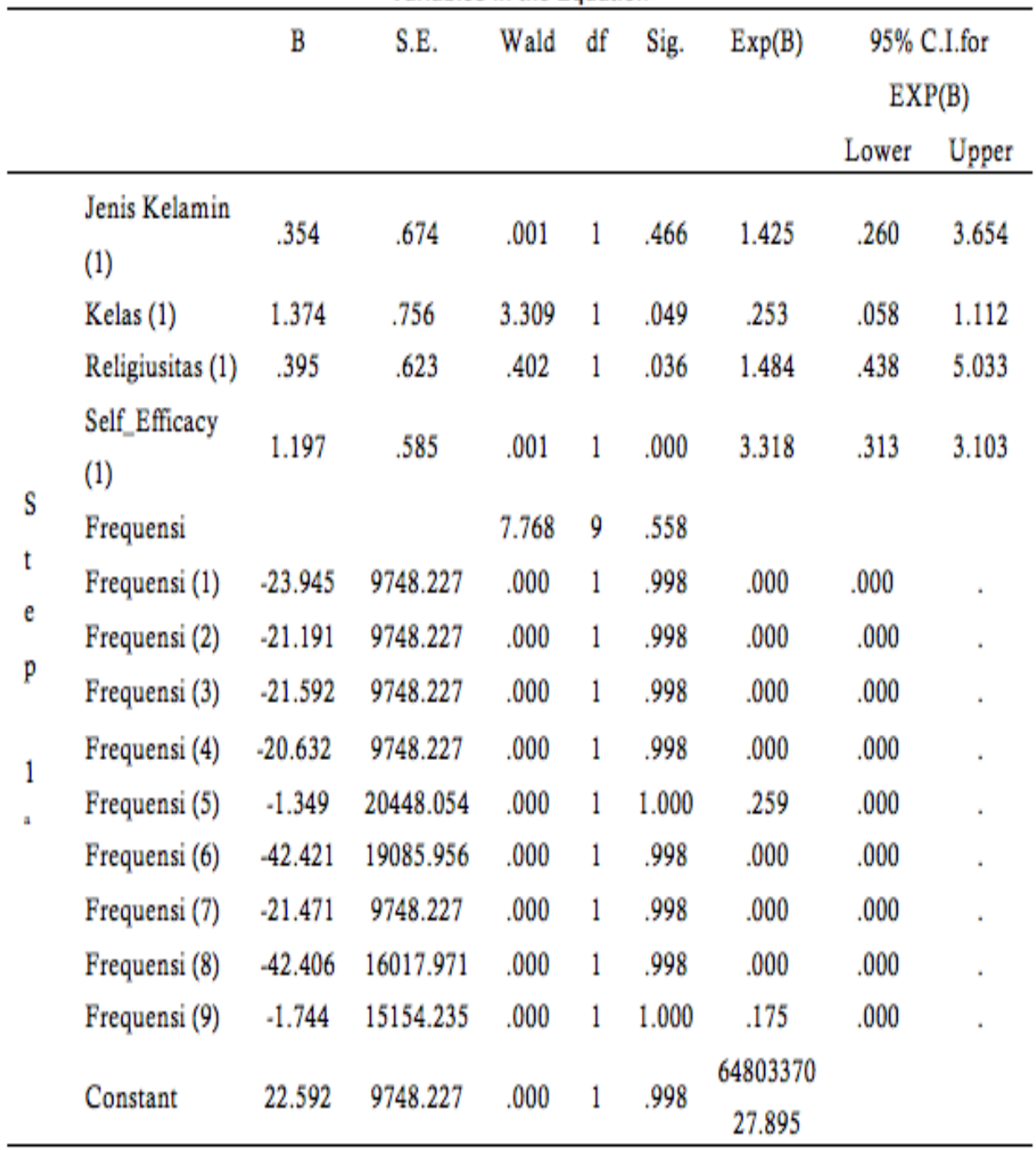

a. Variable(s) entered on step 1: Jenis_Kelamin, Kelas, Religiusitas, Self_Efficacy, Frequensi.

Tabel di atas menunjukkan signifikansi masing-masing variabel bebas, yakni self efficacy, jenis kelamin, kelas dan religiusitas terhadap perilaku menyontek. Dimana keseluruhan variabel bebas terdapat variabel yang signifikansi dalam mempengaruhi perilaku menyontek karena signifikansi masing-masing variabel bebas $<0.05$ diantaranya adalah variabel kelas, religiuitas dan self efficacy. Sedangkan variabel jenis kelamin tidak signifikan. 
Adapun koefisien regresi dalam satuan logit yang diperoleh masing-masing variabel independen adalah sebagai berikut:

1. Variabel religiusitas diperoleh nilai koefisien regresi sebesar 0.395 dengan sig. $0.036($ sig<0.05), yang berarti bahwa variabel religiusitas secara positif mempengaruhi logit perilaku menyontek dan signifikan. Jadi, semakin tinggi atau konsisten religiusitasnya maka semakin rendah logit perilaku menyontek dan setiap kenaikan satu unit pada variabel religiusitas berasosiasi dengan penurunan sebesar 0.395 logit perilaku menyontek.

2. Variabel self-efficacy diperoleh nilai koefisien regresi sebesar 1.197 dengan sig. 0.000 (sig<0.05), yang berarti bahwa variabel religiusitas secara positif mempengaruhi logit perilaku menyontek dan signifikan. Jadi, semakin tinggi self efficacy maka semakin rendah logit perilaku menyontek dan setiap kenaikan satu unit pada variabel self efficacy berasosiasi dengan penurunan sebesar 1.197 logit perilaku menyontek.

3. Variabel jenis kelamin diperoleh nilai koefisien regresi sebesar 0.354 dengan sig. 0.466 ( $\mathrm{sig}>0.05$ ), yang berarti bahwa variabel jenis kelamin secara positif tidak mempengaruhi logit perilaku menyontek dan tidak signifikan. Jadi, tidak ada pengaruh dari jenis kelamin dalam memengaruhi logit perilaku menyontek.

4. Variabel kelas diperoleh nilai koefisien regresi sebesar1.374 dengan sig. 0.049 (sig<0.05), yang berarti bahwa variabel jenis kelamin secara positif tidak mempengaruhi logit perilaku menyontek dan tidak signifikan. Jadi, ada pengaruh dari kelas dalam memengaruhi logit perilaku menyontek. Jadi, kelas atau tingkatan semakin rendah logit perilaku menyontek dan setiap kenaikan satu unit pada variabel kelas berasosiasi dengan penurunan sebesar 1.374 logit perilaku menyontek.

Selanjutnya, berdasarkan tabel 5 pada nilai exp (B) dapat kita simpulkan juga bahwa:

a. Variabel jenis Kelamin (1) yang mengacu pada kategori perempuan, memiliki kecenderungan untuk tidak berperilaku menyontek dengan peluang 1,425 atau 1,42 kali jika dibanding dari pada siswa laki-laki.

b. Variabel kelas (1) yang mengacu pada kategori kelas IX, memiliki kecenderungan untuk berperilaku menyontek dengan peluang 0,253 atau 0,25 kali jika dibanding dari pada kelas VIII.

c. Setiap perubahan pada variabel religiusitas (1) yang mengacu pada kategori konsisten, memiliki kecenderungan untuk tidak berprilaku menyontek dengan peluang 8,680 atau 8,68 kali jika dibanding siswa yang kategori religiusitasnya tidak konsisten.

d. Setiap perubahan pada variabel self efficacy (1) yang mengacu pada kategori tinggi, memiliki kecenderungan untuk tidak berprilaku menyontek 3,318 atau 3,32 kali jika dibanding siswa yang kategorinya self efficacy rendah. 


\section{KESIMPULAN}

Berdasarkan hasil analisis data penelitian maka kesimpulan yang dapat diambil dari penelitian ini adalah: "ada pengaruh yang signifikan dari faktor demografis dan self efficacy terhadap perilaku menyontek". Berdasarkan proporsi varians seluruhnya, logit perilaku menyontek yang dipengaruhi variabel independen (orientasi tujuan dan kepribadian) adalah sebesar $63.1 \%$. Berdasarkan hasil penelitian ini dapat disimpulkan:

1. Terdapat peningkatan signifikansi dengan penambahan model variabel self efficacy, jenis kelamin, kelas dan religiuitas terhadap perilaku menyontek.

2. Siswa perempuan memiliki kecenderungan lebih rendah untuk berperilaku menyontek dibanding siswa laki-laki.

3. Siswa kelas IX memiliki kecenderungan lebih tinggi untuk berperilaku menyontek dibanding kelas VIII.

4. Siswa yang berkategori religiusitasnya konsisten lebih rendah untuk berperilaku menyontek dibanding siswa yang berkategori religiusitasnya tidak konsisten.

5. Siswa yang berkategori self-efficacy tinggi lebih rendah untuk berperilaku menyontek di banding siswa yang berkategori religiusitasnya rendah.

\section{DAFTAR PUSTAKA}

Alawiyah, H. (2011). Pengaruh Self-efficacy, Konformitas dan Goal Orientation terhadap Perilaku menyontek siswa MTs Al-Hidayah Bekasi. Skripsi, UIN Syarif Hidayatullah Jakarta.

Anderman, Eric M. at al. (1998). Motivation and Cheating During Early Adolescence. Journal of Educational Psychology, Universitas of Kentucky.

Anderman, Erick M. dan Murdock, Tamera B. (2007). Psychology of Academic Cheating. USA. Diakses dari http://scholar.google.com. Pada tanggal 1 Juli 2017

Anderman, Eric.M. (2006). Motivational Perspective on Student cheating: Toward an Integrated Model of Academic Dishonesty. Journal Educational Psychology.

Bandura, A. (1997). Self efficacy: The exercise of control. New York: Freeman and Company

Cervone, D. \& Lawrence A. P.(2012). Kepribadian: Teori dan Penelitian. Penerjemah: Aliya Tusyani, dkk. Jakarta: Salemba Humanika.

Feist, J. \& Gregory J. Feist. (2010). Teori Kepribadian Theory Personality. Jakarta: Salemba Humanika

Hartanto, Dody. (2012). Bimbingan dan Konseling Menyontek Mengungkap Akar Masalah dan Solusinya. Jakarta: Indeks.

Hartono. 2010. Statistik Untuk Penelitian. Yogyakarta: Pustaka pelajar

Hosmer, D. W \& Lemeshow, S. (1989). Applied logistic regression (2nded). Canada: A Wiley-Interscience Publication

Kleinbaum, D. G. \& Klein, M. L. (2010). Logistic regression: A self-learning text (3rded). New York:

Liu, Y. (2007). On Goodness-of-Fit of logistic Regression Model. Kansas State 
University, Kansas.

Ormrod, J. E. (2008). Psikologi Pendidikan (membantu siswa tumbuh dan berkembang) jilid 2. (ter.Prof.Dr.Amitya Kumara). Jakarta: Erlangga.

Springer. Menard, S. (2002). Applied logistic regression analysis (2nded). California: Sage Publication, Inc. Pampel, F. C. (2000). The logic of logistic regression: A primer. California: Sage Publication, Inc

Syah, Muhibbin. (2007). Psikologi Pendidikan: Dengan Pendekatan Baru. Bandung: Remaja Rosdakarya.

Tyler, K., Wright, L. B., Watkins, D. S., Thomas, D., Stevens. R., Belle. C. R., Gadson, N., \& Smith, L. T., (2010). Linking home-school dissonance to school-based outcome for African American high school students. Journal of Black Psychology, 36 (4), 410-425

Undang-Undang Republik Indonesia No 20 Tahun 2003 Tentang Sistem Pendidikan Nasional amera B. 